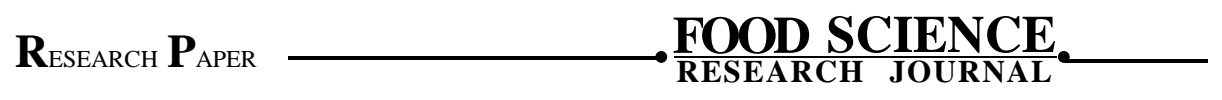
e ISSN-2230-9403 - Visit us : www. researchjournal.co.in Volume 8 | Issue 1 | April, 2017 | 100-104 DOI : 10.15740/HAS/FSRJ/8.1/100-104

\title{
Role of diet and lifestyle of women suffering from breast cancer
}

\author{
Vijayshree Prasad and SeEma Dey
}

\begin{abstract}
Cancer is an intimating disease. It is commonly associated with severe pain, suffering and death. Cancer is not a new disease. The rate of incidence and mortality from breast cancer in India are approximately five times as high as in North America and North Europe. The present study was design to access the diet and lifestyle of women suffering from breast cancer. The data were collected from breast cancer patients under the age of 20-75 years for the study. Food preferences in cancer patients appear to be associated with insufficient intake of nutrients. A high percentage of respondents consumed supari regularly $(60 \%)$ followed by pan masala (22\%) and alcohol (4\%). A high intake of macronutrients, proteins, lipids and carbohydrates in the form of excess energy has some cancer stimulation properties. Stress in the family was one of the major causes ( $48 \%$ ) of breast cancer followed by stress at work place $(6 \%)$ only.
\end{abstract}

Key Words : Diet, Lifestyle, Malignant, Breast cancer

How to cite this article : Prasad, Vijayshree and Dey, Seema (2017). Role of diet and lifestyle of women suffering from breast cancer. Food Sci. Res. J., 8(1): 100-104, DOI : 10.15740/HAS/FSRJ/8.1/100-104.

SEEMA DEY, University Department of Home Science, Ranchi University, RANCHI (JHARKHAND) INDIA

Email : seemadey@ rediffmail.com

Associate Authors' :

VIJAYSHREE PRASAD, University Department of Home Science, Ranchi

University, RANCHI (JHARKHAND) INDIA 